\title{
How labor market institutions affect job creation and productivity growth
}

\section{Key labor market institutions, and the policies that shape them, affect the restructuring that leads to economic growth}

Keywords: entrepreneurship, gazelles, high-growth firms, innovation, labor market policy, productivity

\section{ELEVATOR PITCH}

Economic growth requires factor reallocation across firms and continuous replacement of technologies. Labor market institutions influence economic dynamism by their impact on the supply of a key factor, skilled workers to new and expanding firms, and the shedding of workers from declining and failing firms. Growth-favoring labor market institutions include portable pension plans and other job tenure rights, health insurance untied to the current employer, individualized wage-setting, and public income insurance systems that encourage mobility and risk-taking.

\section{KEY FINDINGS}

Pros
$\oplus$ Continuous transformation and massive job
churning are pervasive traits of modern market
economies.
$\oplus$ High-growth firms are instrumental to economic
growth and net job creation.
$\oplus$ Labor markets should be organized to promote
(potential) high-growth firms, especially through
decentralized and individualized wage-setting and
portable job tenure rights.
$\oplus$ Public policy can facilitate restructuring by
implementing insurance systems that encourage
mobility and risk-taking.

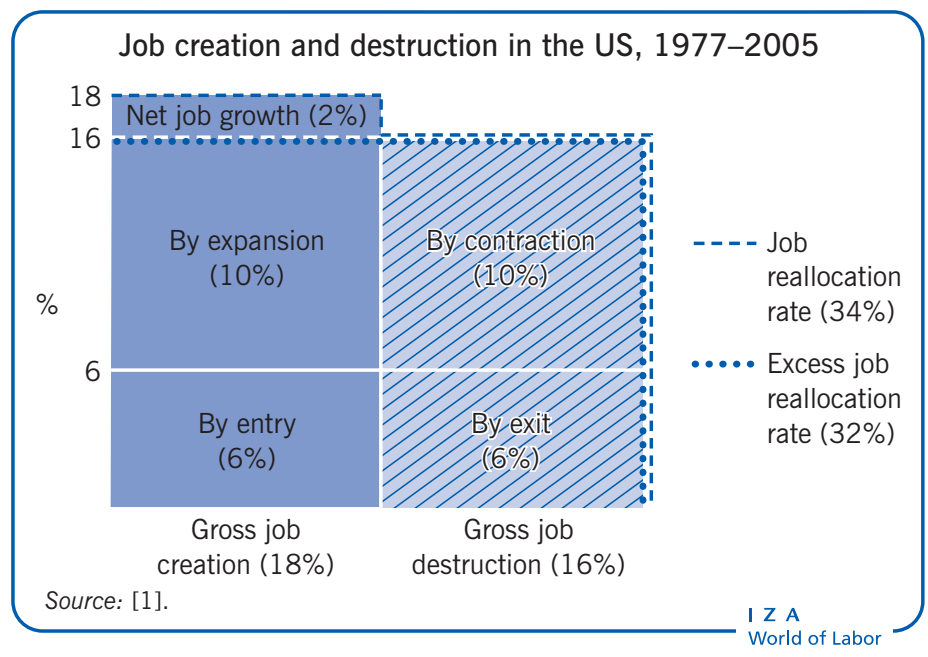

\section{Cons}

- Deregulation of labor markets also has a dark side: it creates insecurity and may lower commitment to employers, which can harm efficiency.

- Deregulation of temporary contracts and staffing agencies cannot substitute for excessive regulation of permanent contracts.

- Labor markets cannot be deregulated in isolation. Appropriate tax policy and competition policy measures are also called for.

\section{AUTHOR'S MAIN MESSAGE}

Economic growth arises as production shifts from less to more successful firms through the reallocation of factors of production. Labor market institutions can advance or impede this restructuring. Overly stringent regulations tend to create a system in which a large share of economic activity occurs in small firms without the ability to grow. Labor markets should be organized to promote (potential) high-growth firms, especially through decentralized and individualized wagesetting, portable job tenure rights, and insurance systems that encourage mobility and risk-taking. 


\section{MOTIVATION}

Aggregate data make changes in economic growth seem fairly small. In developed countries economic growth rarely tops $3 \%$, but such figures conceal a more tumultuous reality.

Economic growth is not primarily about firms growing by a similar percentage or productivity rising in existing jobs because of technological change and more capital per worker. Rather, it comes mainly from churning (firm and job turnover) and restructuringmostly shifts in production from less to more successful firms within narrowly defined industries, rather than from declining to growing sectors.

Growth requires some firms to fail or contract so that resources can move to expanding firms. Entry to and expansion within the marketplace are the flip sides of exit and contraction. Growth presupposes structural transformation: new firms making new goods in new ways and old ones innovating and reorganizing or being dissolved. Labor market institutions can affect this restructuring process, and government policy can help shape them.

\section{DISCUSSION OF PROS AND CONS}

\section{Restructuring and gross job and worker flows}

The turnover of firms and jobs is a common feature of modern economies. In the US, over the three decades 1977-2005, for example, new jobs averaged $18 \%$ of total jobs (see Illustration on p. 1), a third of them in new firms. Over the same period $16 \%$ of jobs were lost through closures and contractions, for annual net job growth of $2 \%$. This $2 \%$ net gain is associated with a gross job reallocation rate of $34 \%(18+16)$ and thus with an excess job reallocation rate-the amount of job-churning beyond the minimum required to accommodate the net employment change-of $32 \%$.

Extensive churning is pervasive in all Organisation for Economic Co-operation and Development (OECD) economies. The average within-industry job reallocation rate in the OECD was 22\% over 1997-2004 (see Figure 1). An astonishing $80 \%$ or more of the reallocation of workers in developed countries takes place within narrowly defined sectors [2].

This reallocation has two main drivers: adjustment among firms with different technologies, and experimentation with improved products, management, and other production systems. Excess job reallocation rates are higher for newer plants because of greater uncertainty, experimentation, and variability in the quality of goods produced.

There are also large differences across countries in the extent of churning. Churning is roughly two-thirds higher in high-end than low-end economies. Worker flows are an estimated 1.5-2.5 times greater in the US than in Europe [4].

\section{The key importance of high-growth firms}

Capitalism entails a process of creative destruction. New ideas continuously challenge old structures, giving rise to structural transformation as successful innovations and new products, firms, and industries arise and obsolete ones decline and vanish. Empirical 
Figure 1. Average within-industry job and worker reallocation rates are high in OECD (economies (\%)

Job reallocation (1997-2004)

Worker reallocation* (2000-2005)

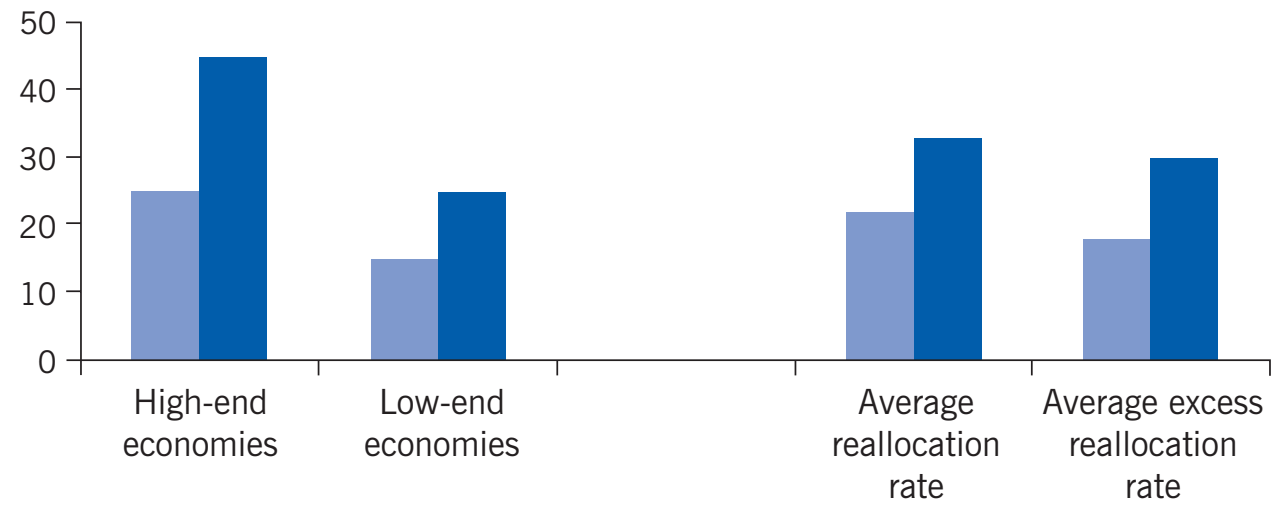

Notes: Data are for 22 OECD countries. High-end and low-end economies are defined as the average for each measure for the upper and lower half of the countries. *Hirings plus separations.

Source: Martin, J. P., and S. Scarpetta. "Setting it right: Employment protection, labour reallocation and productivity." De Economist 160:2 (2012): 89-116. Online at: http://ideas.repec.org/p/iza/izapps/pp27.html [3]

studies point to high-growth firms (sometimes known as gazelles) as the main drivers of this process. In the US, an estimated 1\% of firms create $40 \%$ of all new jobs-and $5 \%$ create almost $70 \%$ of new jobs. A review of the studies of firm growth reveals some common findings [5]:

- High-growth firms are crucial to net job growth, generating a large share of all net jobs. This is particularly pronounced in recessions, when high-growth firms continue to grow while other firms decline.

- Small firms are overrepresented among high-growth firms, but these firms come in all sizes. A small subgroup of large high-growth firms are major job creators.

- High-growth firms are younger on average.

- Young and small high-growth firms grow organically (not through mergers and acquisitions) and make a larger contribution to net employment growth than do larger and older high-growth firms.

- High-growth firms are present in all industries, though they are slightly overrepresented in service industries.

Young firms that survive have higher productivity and grow more rapidly than more mature firms [1], suggesting an "up or out" dynamic. Firms have higher productivity and grow more rapidly than incumbents or they fail.

The evidence suggests that high-growth firms, especially those that grow rapidly when young and small, are instrumental to economic growth. A 2007 study judges that half of aggregate productivity growth results from the reallocation of resources from low- to high-productivity firms within an industry and that roughly half of that emanates from startups and closures [2]. 
Modern societies are rich webs of formal and informal institutions that differ greatly and that shape the incentives of economic actors and the functioning of markets. This paper looks at the effect of the organization of labor markets only, although many other institutions also affect structural transformation.

\section{Effects of labor market regulations on productivity}

Most OECD countries have reformed and eased their systems of employment protection in recent decades. But large differences remain in the strictness of employment protection, with Canada, the UK, and the US at the looser end and the Mediterranean countries, Mexico, and Turkey at the stricter end [2], [6]. Most of the regulatory easing has affected temporary employment contracts.

There is considerable evidence to support the claim that, in general, when labor markets are less regulated, inputs flow more readily to high-productivity firms, enabling them to grow in line with their inherent potential. Stringent hiring and firing regulations, which curb job flows most to industries and firms that require frequent labor adjustments, tend to affect new firms and failing firms more than incumbent firms.

The effect on productivity of regulations governing employee dismissals in OECD countries has been examined using aggregate cross-country data on the stringency of employment protection rules and industry-level data on productivity over the period 1982-2003 [7]. Dismissal regulations have a depressing impact on productivity growth in the industries where layoff restrictions are more likely to be binding.

Distortions at the producer level, such as high regulation-induced costs for shedding labor, weaken the relationship between productivity and firm size within an industry, according to a study based on harmonized firm-level data for the US and seven European countries [8]. The relationship between productivity and firm size is much stronger in the US than in European countries with more stringent labor market regulations. Thus, in both cases the relationship between productivity and firm growth is stronger where dismissal regulations, or other labor market regulations, are less stringent [7], [8].

The latter study also found that high-risk, innovative sectors are smaller in countries with strict employment protection legislation, helping explain the slowdown in productivity in Europe compared with the US since the mid-1990s [8]. Other studies have found that US firms introduce more productivity-enhancing information technology than their European competitors, largely because of the more efficient management practices that evolve in the more deregulated US labor market. Similarly, studies exploiting differences in the timing and adoption of stricter job security mandates in US states have found a negative effect on firm entry rates, job flows, and total factor productivity growth.

In a flexible labor market, the marginal product of labor and the average wage in an industry should tend toward equality across firms. Taking advantage of a legislative change in Chile that raised firing costs, a study measured the gap between the marginal product of labor and the average wage in an industry before and after the reform. The gap increased after the legislation, which suggests that the legislation reduced allocative efficiency [9].

Studies have suggested that total factor productivity could increase by as much as $30-$ $60 \%$ in China and India if they were to attain the US level of allocative efficiency across 


\begin{abstract}
Allocative efficiency
Allocative efficiency occurs when the mix of products produced matches consumer preferences (where marginal benefit equals marginal cost). These products (and services) are the most profitable, thereby promoting economic growth.
\end{abstract}

firms within individual industries. This result implies that plants with low total factor productivity are too large and plants with high total factor productivity are too small relative to the US benchmark of allocative efficiency.

Other research has revealed a strong quantitative effect of strict employment protection legislation on the rate of reallocation. By relaxing employment protection rules, countries with the strictest legislation could increase their reallocation rate by an estimated $50 \%$ in the most dynamic sectors-those that benefit most from flexibility. The effect appears to be particularly strong on the entry-exit margin, which is, arguably, especially important for creative destruction.

\title{
Reallocation rate
}

The number of jobs lost in contracting or exiting firms plus the number of jobs gained in new or expanding firms in a certain period divided by the average number of existing jobs.

\section{Labor market institutions and high-impact entrepreneurship}

How should labor markets be regulated and organized so that the economy can benefit most from the dynamic process of creative destruction? Three areas seem to be particularly important for promoting high-impact entrepreneurship and high-growth firms:

- labor market regulations, especially job security mandates;

- $\quad$ wage-setting institutions;

- $\quad$ social insurance systems, including health insurance.

\section{High-impact entrepreneurship}

Actions of individuals responding to market opportunities by bringing innovations to market that create sizable growth as opposed to mere imitators, sometimes called replicative entrepreneurship.

\section{Labor market regulations}

Less stringent labor market regulations, by enabling firms to adjust their workforce in response to market fluctuations, increase the flexibility of high-risk entrepreneurial companies, easing their evolution into high-growth firms [10]. Empirical findings suggest 
Figure 2. Stricter employment protection is associated with a lower share of early-stage (entrepreneurship with high-growth expectations, 2004-2009

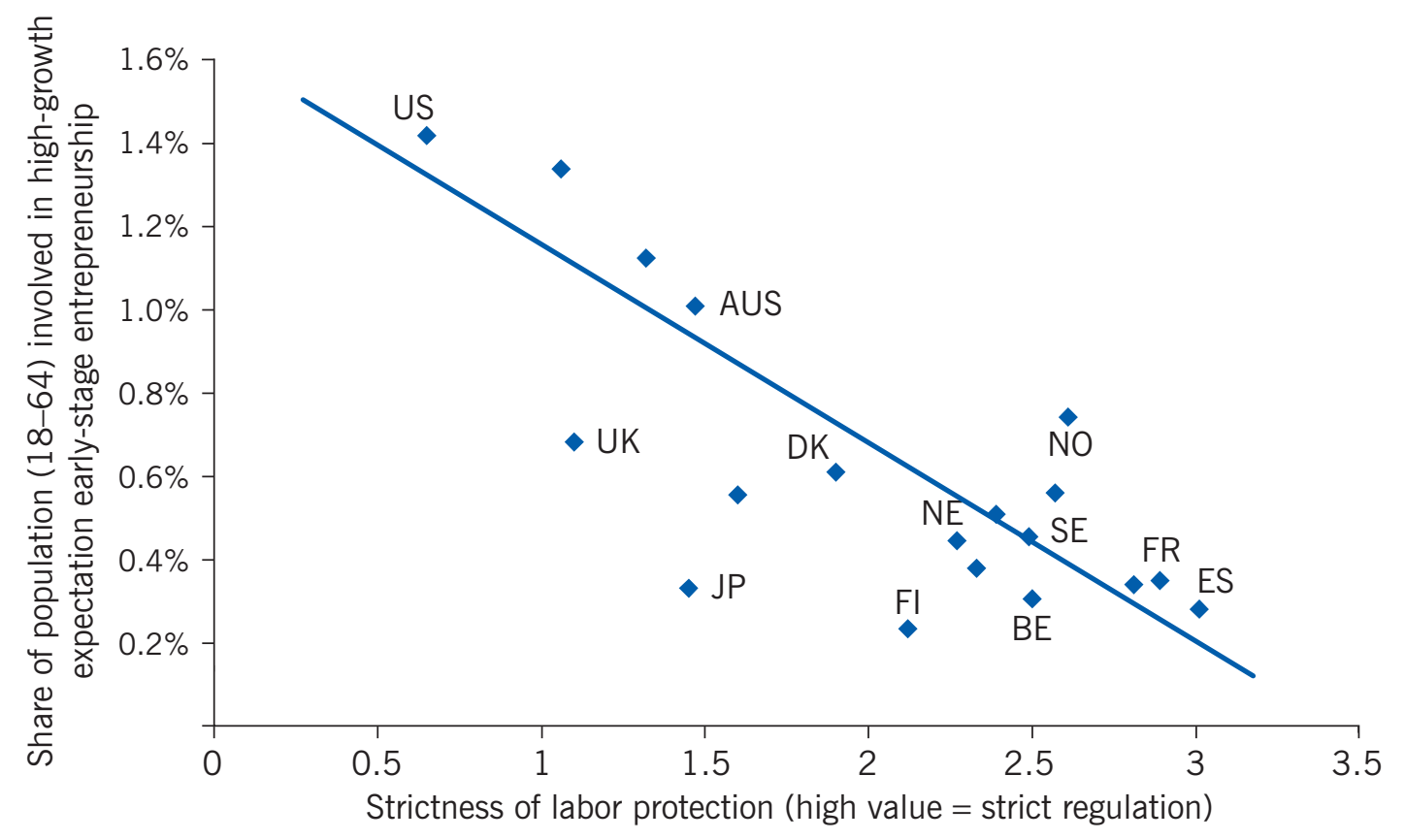

Notes: Employment protection refers to the 2004 OECD index (version 2); high-growth expectation early-stage entrepreneurship is the average over 2004-2009 according to the Global Entrepreneurship Monitor (GEM); $r=0.76$. Source: Bosma, N., and J. Levie. Global Entrepreneurship Monitor 2009 Global Report. Global Entrepreneurship Monitor, 2010. Online at: http://www.baf.cuhk.edu.hk/pdf/GEM_Global_2009_Report.pdf

that stringent job security provisions and other regulations that unduly restrict the flexibility of employment contracting harm early-stage entrepreneurs with high-growth expectations more than they do mature firms and firms without growth aspirations. Both the rate at which workers leave jobs and the rate at which employers eliminate jobs decline with increasing firm size, age, and capital intensity. Thus, stringent regulations are associated with a lower share of early-stage entrepreneurs with high-growth expectations (see Figure 2). Furthermore, stricter and far-reaching labor protection legislation increases an employee's opportunity cost of changing employers or leaving a secure salaried job to become self-employed.

If formal employment is highly regulated, incentives to circumvent the regulations are strong. In several European countries avoidance measures include increased selfemployment, a larger underground economy, and greater reliance on temporary employment-all forms of employment that are beyond the reach of government job security regulations. The proportion of the workforce on temporary contracts and working in staffing service firms is also on the rise. Staff on temporary contracts are less motivated to invest in firm-specific skills and to commit to the firm than are employees on permanent contracts. Thus, it becomes more difficult for firms to attract workers with highly-valued skills.

These evasive measures do little to support high-growth firms and welfare-enhancing structural transformation. The greater freedom of contracting available to very small firms, which may be able to avoid unionization and collective bargaining agreements, is lost once firms grow larger. Thus, stringent regulations tend to create a system in which 
a large share of economic activity occurs in small firms without the ability or desire to become high-growth firms.

\section{Wage-setting institutions}

Empirical studies find high-growth firms to be younger and smaller than other firms on average. Wages are consistently higher in larger firms in slow-growth industries than in new firms, even after controlling for observable worker characteristics and other job attributes. Industries at the low end of the wage distribution are generally in services rather than in manufacturing.

Thus, centralized wage bargaining in highly regulated labor markets is likely to disadvantage potential high-growth firms, which are mainly small firms. An artificially compressed wage structure makes it more difficult for profitable high-productivity firms to use salaries as an incentive to recruit skilled employees. High-growth firms tend to pay low salaries at the beginning of their life cycle. They cannot bear high wage costs at a time when they are still developing their product and their marketing channels. When young high-growth firms become more productive, they begin to grow rapidly-and so do their salaries. A compressed wage structure, especially one pegging the minimum wage above the market equilibrium wage, tends to choke potential high-growth firms in their infancy.

Also, centralized wage-setting institutions disadvantage potential high-growth firms by closely tying wages to easily observable job and worker characteristics, such as occupation, education, experience, and seniority. If wages are set in negotiations far from the individual workplace and therefore do not take intra-firm differences in productivity and productivity growth into account-particularly in young and rapidly expanding industries [5]-the cooperation among key actors needed for high-growth firms is impeded.

\section{Social insurance system}

While in theory an extensive and generous public social insurance system can encourage entrepreneurship by insuring against unfavorable outcomes, this connection has not been empirically tested. And in labor markets where job security is closely linked to job tenure, this relationship may not hold. What matters is the opportunity cost, or how much income security an employee gives up by transferring to self-employment or to a risky job in an entrepreneurial firm. For a tenured employee with a low-risk employer, the opportunity cost rises considerably in many OECD countries.

In many countries important insurance benefits are linked to employment, such as health insurance in the US. That ties many workers and potential entrepreneurs to employment in large companies that provide generous health insurance. Decoupling social insurance from employment would increase labor flexibility by reducing fears of losing important benefits that are tied to employment. In Denmark, generous welfare systems are combined with weak job security mandates, or "flexicurity." In other countries, the structure of social insurance systems in combination with job security legislation tends to penalize individuals who assume entrepreneurial risk. In Sweden, for example, an individual who voluntarily gives up a tenured position for self-employment 
may be left with no more social security than that provided by (means-tested) social welfare.

Furthermore, the channels that transfer savings to various investment activities influence the types of business organization that obtains credit. Pension funds are less likely to channel funds to entrepreneurs than are venture capital firms. That means that the composition of national savings is not neutral in its impact on entrepreneurship and business development. Less credit will be available to small businesses if individuals are required to keep a large part of their savings in a national pension fund system than if they are allowed greater choice.

\section{Synthesizing the effects of labor market institutions}

The need for experimentation to find more efficient combinations of factors of production is likely to be large in new firms and industries, especially in potential highgrowth firms. Thus, strictly regulated job security, wage setting, and social insurance systems influence incentives for potential and existing high-growth firms by affecting their freedom of contracting and limiting the possible combinations of factors of production.

The most important channel through which stringent labor market institutions affect high-growth firms and high-impact entrepreneurship is by narrowing the supply of skilled workers to expanding and restructuring firms. A dynamic economy requires free flows of large numbers of workers. When the opportunity cost of leaving a tenured position rises for employees and the fixed cost of hiring rises for employers because hiring decisions are costly to reverse, it is harder to recruit workers with the right skills and firms may be hesitant to expand beyond a certain size. In addition, a great deal of entrepreneurial effort may be expended on evasive rather than on directly productive activities.

If temporary contracts are used systematically to circumvent labor market regulations tied to permanent employment, businesses that depend on high-skill labor and on-thejob learning are disadvantaged. Legal and institutional hurdles that prevent firms from laying off workers who underperform discourage potential high-growth firms from expanding. The opportunity cost of becoming self-employed or starting a new business depends on how labor markets are regulated and how regulations interact with the social insurance system. When social security benefits are closely tied to tenured positions, the opportunity cost of leaving is high.

Austria reduced the costs of labor mobility for both employers and employees through reforms in 2003 that converted uncertain firing/resigning costs into a system of individual savings accounts, funded by an employer payroll tax. For employers, these accounts provide certainty at the time of hiring about the cost of any future dismissal. For workers, these accounts reduce the costs associated with leaving a firm because they do not lose their entitlement to severance pay.

Some degree of job protection is valuable, since it encourages worker commitment and incentives to invest in firm-specific human capital. Policymakers need to know where to draw the line between protections that provide job stability and those that discourage high-growth firms. 


\section{LIMITATIONS AND GAPS}

One limitation of many of the studies is that they use the US economy as a benchmark, thus assuming the US outcome to be the outcome of unfettered labor markets. Any negative difference relative to the US in terms of productivity growth, reallocation rates, and other variables is then assigned to differences in various labor regulations. There is always a risk of explaining too much, since other potential explanations are not considered.

More specifically, much of the research summarized here focuses on liberal market economies as distinct from coordinated market economies. Liberal market economies appear to require more radical innovation and greater turnover of jobs and firms than coordinated market economies in order to thrive. Coordinated market economies may be equally successful through a greater emphasis on incremental innovation, longer job tenure, and complementary institutions to facilitate firm-specific training and public support schemes for retraining in cases of redundancies and plant closures.

\section{SUMMARY AND POLICY ADVICE}

A small share of all firms play a disproportionate role in the economy, favoring a policy emphasis on high-growth firms and high-impact entrepreneurship. Most potential highgrowth firms fail, but the few that succeed are crucial for growth.

Labor market institutions affect high-growth firms by influencing the supply of skilled workers to new or expanding firms. Legal and institutional hurdles preventing firms from laying off workers who underperform discourage potential high-growth firms from expanding. Also, the opportunity cost of changing jobs or becoming self-employed rises where social security benefits are closely tied to tenured positions, discouraging entrepreneurship.

Reallocation and dynamism are favored by policies that support portable job tenure rights and pension plans, health insurance decoupled from the current employer, decentralized and individualized wage-setting, and government income-insurance systems that encourage mobility and risk-taking. Labor market reforms should be part of a comprehensive package that includes other areas, notably tax and competition policies.

\section{Acknowledgments}

The author thanks two anonymous referees and the IZA World of Labor editors for many helpful suggestions on earlier drafts. This article is partly based on [11].

\section{Competing interests}

The IZA World of Labor project is committed to the IZA Guiding Principles of Research Integrity. The author declares to have observed these principles.

(C) Magnus Henrekson 


\section{REFERENCES}

\section{Further reading}

Bloom, N., R. Sadun, and J. Van Reenen. "Americans do IT better: US multinationals and the productivity miracle.” American Economic Review 102:1 (2012): 167-201.

Bosma, N., and J. Levie. Global Entrepreneurship Monitor 2009 Executive Report. Global Entrepreneurship Monitor, 2010. Online at: http://www.baf.cuhk.edu.hk/pdf/GEM_Global_2009_Report.pdf

Henrekson, M., and D. Johansson. "Gazelles as job creators-A survey and interpretation of the evidence." Small Business Economics 35:2 (2010): 227-244. Online at: http://link.springer.com/content/ pdf/10.1007\%2Fs11187-009-9172-z.pdf

Stangler, D. High-Growth Firms and the Future of the American Economy. Kauffman Foundation research series "Firm Formation and Economic Growth," 2010. Online at: http://www.kauffman.org/ uploadedfiles/high-growth-firms-study.pdf

\section{Key references}

[1] Davis, S. J., J. Haltiwanger, and R. Jarmin. Young Businesses, Economic Churning, and Productivity Gains. Kauffman Foundation research series "Turmoil and Growth," 2008. Online at: http:// www.kauffman.org/uploadedFiles/TurmoilandGrowth060208.pdf

[2] Caballero, R. J. Specificity and the Macroeconomics of Restructuring. Cambridge, MA: MIT Press, 2007.

[3] Martin, J. P., and S. Scarpetta. "Setting it right: Employment protection, labour reallocation and productivity." De Economist 160:2 (2012): 89-116. Online at: http://ideas.repec.org/p/iza/ izapps/pp27.html

[4] Pries, M., and R. Rogerson. "Hiring policies, labor market institutions, and labor market flows." Journal of Political Economy 113:4 (2005): 811-839. Online at: http://merlin.fae.ua.es/ mbosch/Labor\%20Macro/Hiring_Pries_Rogerson.pdf

[5] Henrekson, M., and D. Johansson. "Competencies and institutions fostering high-growth firms." Foundations and Trends in Entrepreneurship 5:1 (2009): 1-80. Online at: http://tinyurl.com/ p9serdc

[6] Skedinger, P. Employment Protection Legislation: Evolution, Effects, Winners and Losers. Cheltenham, UK: Edward Elgar, 2010.

[7] Bassanini, A., L. Nunziata, and D. Venn. "Job protection legislation and productivity growth in OECD countries.” Economic Policy 24:58 (2009): 349-402.

[8] Bartelsman, E., J. Haltiwanger, and S. Scarpetta. "Cross-country differences in productivity: The role of allocation and selection." American Economic Review 103:1 (2013): 305-334. Online at: http://www.econstor.eu/dspace/bitstream/10419/36105/1/616720548.pdf

[9] Petrin, A., and J. Sivadasan. "Estimating lost output from allocative inefficiency, with application to Chile and firing costs." Review of Economics and Statistics 95:1 (2013): 286-301.

[10] Acs, Z. J. "Foundations of high impact entrepreneurship." Foundations and Trends in Entrepreneurship 4:6 (2008): 535-620.

[11] Henrekson M., D. Johansson, and M. Stenkula. "Taxation, labor market policy and high-impact entrepreneurship." Journal of Industry, Competition and Trade 10:3-4 (2010): 275-296.

The full reference list for this article is available from the IZA World of Labor website (http://wol.iza.org/articles/how-labor-market-institutions-affect-job-creation-andproductivity-growth). 